\title{
New Endemic Iguanid Lizards from the Famatina Mountains of Western Argentina
}

\author{
José M. Cei๋ \\ Instituto Biologia Animal, Universidad Nacional de Cuyo, Mendoza, Argentina
}

\begin{abstract}
The first herpetological information on the Sierra de Famatina massif $(6250 \mathrm{~m})$, La Rioja Province, Argentina, includes two new species of Phymaturus and Liolaemus living at altitudes from 3600 to $4200 \mathrm{~m}$. Taxonomic and ecological relationships between these isolated tropidurine iguanids and nearby related species from the Cordilleran highlands are discussed. A montane species-group comprising Liolaemus ruibali, $L$. duellmani and $L$. famatinae $s p$. nov. is suggested by morphological affinities.
\end{abstract}

The Sierra de Famatina extends between $28^{\circ}$ and $29^{\circ} 30^{\prime}$ south latitude in western Argentina, La Rioja Province (Fig. 1). It is a longitudinally enlarged Ordovician massif surrounded by Permo-Triassic sediments on its border, and showing extensive, probably Devonian, granitic intrusions on the summits. Its eroded metamorphic rocks were uplifted during the PlioPleistocene, reaching at present the remarkable altitude of 6250 meters (Leanza, 1972). In the summer months of 1979 I was able to climb the eastern slopes of the scarcely accessible mountains from a level of about 1700 meters, in the neighborhood of the villages of Famatina and Corrales, up to about 5000 meters, near the snowline. Two new species of iguanids, belonging to the genera Phymaturus and Liolaemus, were found in this heretofore zoologically unknown and very isolated montane environment. Their description and a discussion of their relationships with the Cordilleran species of the same genera, as well as of the origins and adaptive trends of the small endemic herpetofauna of the Famatina massif, follow.

Comparison of the species was done by standard morphological measurements as well as semi-microelectrophoretic tests that compared serum proteins. Chemetron cellogel strips were used, with a sodium Veronal $0.04 \mathrm{M}$ buffer solution (application $1.5 \mathrm{ul} / 9 \mathrm{~mm}$; run for 30 minutes, at $200 \mathrm{~V} ; \mathrm{pH} 7.0)$. Strips were treated with Amido Black and analyzed by densitometry.

Specimens examined have been deposited in the Museo Zoologico, Firenze, Italy (MF); Instituto Biologia Animal, Universidad Nacional de Cuyo, Mendoza, Argentina (IBA-UNC); and in the author's Diagnostic Collection (JMC-DC).

-Present Address: Rancho Somuncurá, Rua F. de Figueiredo, Birre, 2750 Cascais, Portugal. 


\section{Phymaturus mallimaccii sp. nov.}

(Fig. 2)

Holotype. MF 23862. male, 2 km E Cueva de Perez, 4200 m, Sierra de Famatina, La Rioja Province, Argentina, 2 March 1979, J. M. Cei.

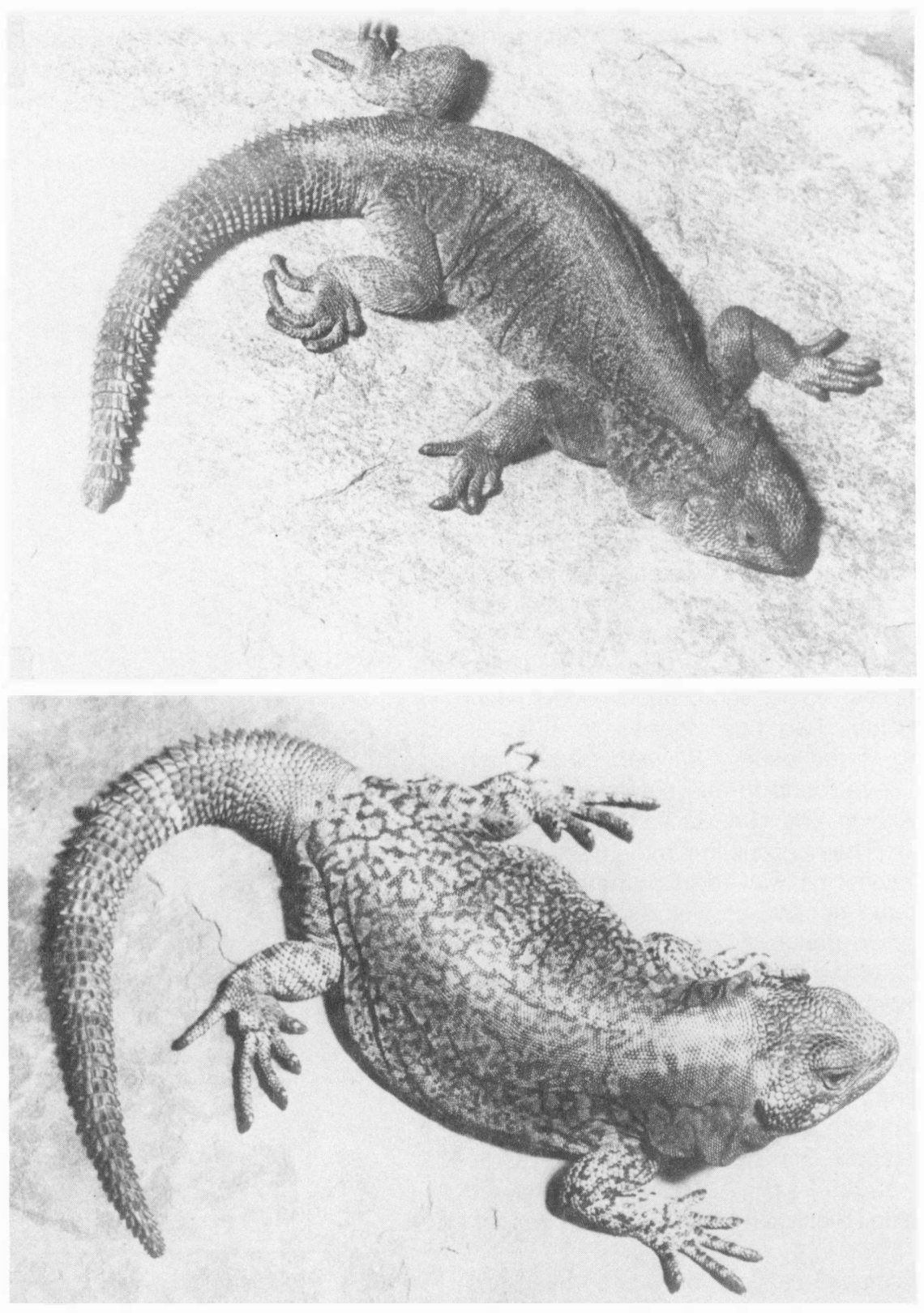

FIGURE 2. Top, Phymaturus mallimaccii male from Famatina mountains, La Rioja Province, Argentina, at about $4000 \mathrm{~m}$. Bottom. Phymaturus palluma male from Uspallata highlands, Mendoza Province, Argentina at about $3000 \mathrm{~m}$. Slightly reduced. 
Paratypes. MF 23861, 23863, 23864, 23865, a male, two females, a young male; JMC-DC 73, 74 , a male and female; same locality as the type.

Description of holotype. Head scales undifferentiated and bulky, slightly rugose; rostral distinct, twice as wide as high, separated from nasals by two scale rows; nostrils opening anterolaterally; prefrontals, frontals and frontoparietals irregular; interparietal enlarged with central "eye" very distinct; parietals indistinguishable; four slightly distinct supraoculars; circumorbitals not evident; three-four rows of irregular scales between supraoculars and ciliaries; subocular enlarged, separated from supralabials by 2-4 scale rows; ten supralabials; eleven infralabials; temporals large, almost conical. A short blunt canthal ridge, followed by seven irregular ciliaries; snout blunt, loreal region strongly depressed; eyelids finely granular, unfringed; ear opening square, bordered anteriorly by moderately acuminate scales. Distance between anterior border of eye and tip of snout slightly greater than diameter of eye. Head subtriangular, slightly wider than long, one fifth body body length. Body slender, tail equal to body length; fourth toe of adpressed hind limb not reaching axilla; fourth finger of adpressed forelimb surpassing tip of snout. Dorsal scales of neck conical, irregularly enlarged; dorsal body scales very irregular, subimbricate, almost juxtaposed, becoming smaller on sides. Ventral scales quadrangular, imbricate, larger than dorsal; caudal scales in regular rows, dorsally prominent, strongly conical and mucronate behind, ventrally weakly carinate. Limb scales blunt, subimbricate or juxtaposed dorsally, smooth, irregular and subimbricate ventrally, granular on inner surface of arm and thigh. Scales around body 210; eight preanal pores; 29 carinate lamellae under fourth toe; 21 carinate lamellae under fourth finger. Length of head equal to length of $\mathbf{4 0}$ middorsal scales. A remarkable, swollen skin fold from ear opening to antehumeral region.

Ground color yellow on dorsum and tail in the living animal (bluish in the preserved specimen), with profusely scattered, irregular dark brown marks on sides and tail; head brown. Ventrally yellowish; throat and preanal pores pale brown.

Measurements of holotype $(\mathrm{mm})$ : total length 173 , snout-vent 87 , tail 87 , axilla-groin 45.5 , head length 16 , head width 16.5 forelimb 31 , hind limb 45.5 .

Variation in the adult paratypes. Measurements in mm of males; snout-vent 91-95, tail 74-96, axilla-groin 46-49, head length 17.5-18, head width 18.5-19, forelimb 32.5-34, hind limb 47-48; of females: snout-vent 92-98-100, tail 74-86, axilla-groin 52.5-53-54, head length 16.5-17.5-17.5, head width 17-17-18, forelimb 33.5-33.5-34, hind limb 45-46-46.5. In males, scales at midbody 196-202, in head length 40-43; lamellae under fourth toe 28-29, under fourth finger 21-23. In females, scales at midbody 188-190-212, in head length 37-38-38; lamellae under fourth toe 28-28-29, under fourth finger 23-23-24.

Color pattern quite uniform in males; $7-8$ preanal pores present. Dorsal coloration in females and young specimens reddish or brownish, speckled with dark brown on sides and head. Ventrally grayish or brownish, with red-orange shades on flank and chest.

Distribution. The species is known only from the type-locality, from 3800 to $4200 \mathrm{~m}$.

Etymology. The species is named after Dr. Hugo S. Mallimacci, geologist of the Geological Mining Service, Argentine Army, who first observed it.

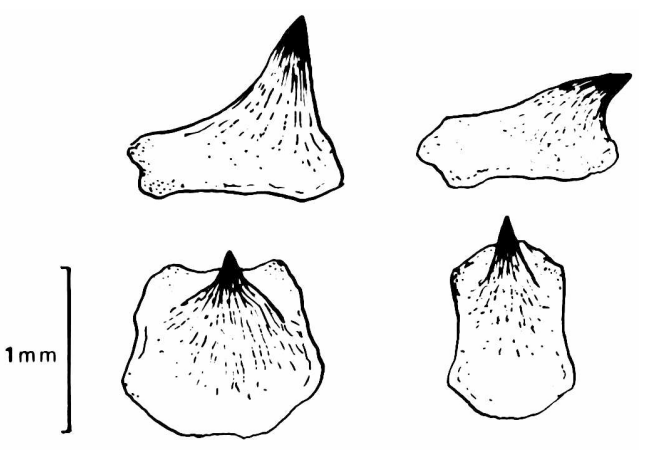

FIGURE 3. Caudal scales, lateral and dorsal view. Left, Phymaturus palluma; right, Phymaturus mallimaccii.

Remarks. Phymaturus mallimaccii is easily separated from the Andean Phymaturus palluma populations in having smaller males, a lower number of scales at midbody, smaller and very irregular dorsal scales (twice larger in palluma), smaller ventral scales, more scale rows between subocular and supralabials, two scale rows between nasal and rostral (three in pa/luma whose rostral scale is almost indistinguishable), smaller preanal scales, a larger number of lamellae under the fourth toe, a different size and shape of caudal scales (Fig. 3) and a very different color pattern in males and females. This lizard is not easily found, living under large stones, for the most part conglo- 
merates of pleistocene age scattered on the slopes of the Sierra. It is a rather nimble saxicolous form, foraging during the warmest hours of midday and early evening. It feeds on composite flowers, specially the cushion-like Werneria and Hypochoeris. As in other species of the genus (Donoso, 1966), pregnant females of $P$. mallimaccii presumably give birth to 2-3 broods in late January and February.

\section{Liolaemus famatinae sp. nov}

(Fig. 4)

Holotype. MF 23821, male, 2 km E Cueva de Perez, 4100 m, Sierra de Famatina, La Rioja Province, Argentina, 2 March 1979, J. M. Cei.
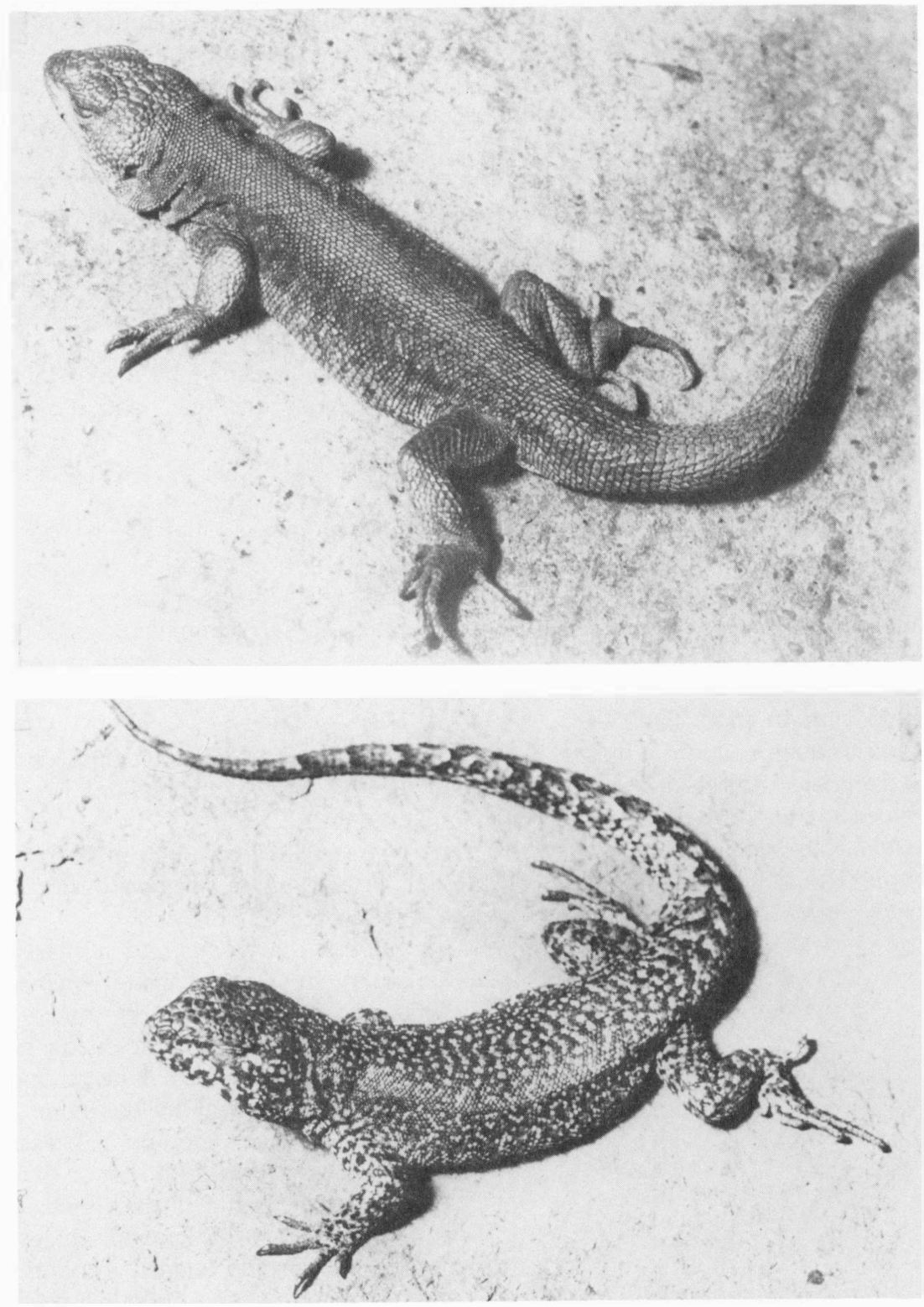

FIGURE 4. Top, Liolaemus famatinae male from Famatina mountains, La Rioja Province, Argentina, at about $4200 \mathrm{~m}$. Bottom, Liolaemus ruibali male from Uspallata highlands, Mendoza Province, Argentina, at about $3000 \mathrm{~m}$. Slightly magnified. 
Paratypes. MF 23822-23845, 23855, 23856, 26 males, same data as holotype; MF 2384623854, 23857, ten females, 23858-23860, three young, same; IBA-UNC 1344-1-10, ten males, near Cueva de Perez, Sierra de Famatina, 3800-4000 m; JMC-DC 75-76, a male and a female, same data as holotype. All collected by J. M. Cei, 27 February-3 March 1979.

Description of holotype. Upper head scales slightly rugose, irregular, well differentiated; rostral wider than high, separated from nasal by a single scale row; prefrontals regularly arranged; two azygous frontals; frontoparietals irregular; interparietal smaller than parietal; seven distinct supraoculars surrounded by small polygonal circumorbitals; three rows of moderate, polygonal scales between supraoculars and ciliaries; subocular enlarged, separated from supralabials by a single scale row; eight supralabials, 5-6 infralabials; temporal scales enlarged, smooth, irregularly arranged. A blunt canthal, followed by six narrow overlapping ciliaries; snout moderately blunt; nostrils opening laterally; loreal region depressed; eyelids granular, unfringed; ear opening transverse rectangular. Head subtriangular, longer than wide, less than one fourth body length. Distance between anterior border of eye and tip of snout slightly longer than diameter of eye.

Body slender, tail longer than snout-vent length; fourth toe of adpressed hind limb surpassing axilla; fourth finger of adpressed forelimb not reaching tip of snout. Dorsal scales of neck almost conical, subimbricate; lateral scales of neck granular; dorsal body scales subimbricate, smooth or faintly keeled, slightly heterogeneous, smaller and almost conical on sides of body; ventral scales rounded, imbricate, about $1 \frac{1}{2}$ times as large as dorsals; caudal scales distinctly carinate, quadrangular, in regular rings, imbricate, ventrally keeled on distal part of tail; limb scales enlarged, imbricate and smooth, granular on posterior surface of arm and thigh. Scales around the body 56; seven orange preanal pores; 23 carinate lamellae under fourth toe, 18 under fourth finger. Length of head equal to length of 21 middorsal scales. Femoral patches not evident. Three lateral skin folds behind the ear opening and in the antehumeral region.

Ground color reddish ochre (brownish in the preserved specimen) with a few bluish scales on sides. Ventrally whitish, with sparse pigmentation on abdominal scales and a diffuse lateral orange shade between axilla and groin.

Measurements of holotype $(\mathrm{mm})$ : total length 125 , snout-vent 53 , tail 72 , axilla-groin 24 , head length 12.5, head width 11 , forelimb 18, hind limb 27 .

Variation in the adult paratypes. Minimum, mean plus standard error and maximum of measurements $(\mathrm{mm})$ : snout-vent 37 males, 44 ( $51.41 \pm 0.07) 58,11$ females, $45(48.90 \pm 0.09)$ 55; tail, 16 males, 60 (70.06 \pm 1.60$) 82,6$ females, 61 (66.83 \pm 1.80$)$ 74; axilla-groin, 27 males, 19 $(23.87 \pm 0.46) 28,11$ females, $22(24.54 \pm 0.61) 29$; head length, 27 males $10(11.12 \pm 0.15) 12.5$, 11 females, $9.5(10.45 \pm 0.15) 11$; head width, 27 males, $8.5(10.25 \pm 0.16) 12,11$ females, 8.5 (9.22 \pm 0.17$)$ 10.5; forelimb, 27 males, 15 (16.81 \pm 0.25$)$ 19, 11 females, 15 (16.09 \pm 0.30$)$ 17.5; hind limb, 27 males, $22.5(26.50 \pm 0.40) 30,11$ females, $24(25.27 \pm 0.38) 28$; scales at midbody, 51 males and females, $60(66.68 \pm 0.40) 72$; scales in the head length, 51 males and females, 16 $(20.23 \pm 0.30) 27$; lamellae under fourth toe, 51 males and females, $22(24.24 \pm 0.20) 28$; lamellae under fourth finger, 51 males and females, $16(18.00 \pm 0.20) 22$.

No significant sex differences were found in measurements except for head width. Preanal pores are 2-7 in males. Autotomy is very common; broken or regenerated tails were observed in about $50 \%$ of inidividuals in the sample. Dorsal scales are frequently more distinctly keeled than in the holotype. Female paratypes usually differ from males in dorsal coloration, showing a pale ochre background with dorsolateral transverse series of symmetrical, rounded and oblique, whitebordered brown spots. This pattern is rarely observed in males, the reddish or ochraceous, uniform color of the holotype is the predominant dorsal pattern in this sex. Scattered lateral blue scales and a deep dorsolateral brick-red shading are often present in males. Also the lateroventral orangeyellow coloration is noticeably variable in both sexes. Melanistic individuals were found.

Distribution. The species is known only from the type-locality from 3700 to $4200 \mathrm{~m}$.

Etymology. The name refers to the extra-Andean mountains where the lizard was discovered.

Remarks. Liolaemus famatinae is distinguishable from its nearest relative, $L$. ruibali (Donoso, 1961), in having a higher number of scales at midbody (64-91 versus 56-72), larger dorsal and ventral scales, slightly heterogeneous keeled dorsal scales, a greater number of scales in the head 
length, a larger forelimb, a lower number of lamellae under the fourth toe and finger, a different coloration. All of these characters are significantly dissimilar, at a $P<0.001$ (Student-Fisher test). Likewise $L$. famatinae cannot be allocated to any other Argentine Liolaemus species-group by several characteristics in size, limbs, lepidosis, etc.

The Famatina lizard is found in the high Andean steppe of Poa and Festuca, living under bunch grass or stones in the rocky slopes of the Sierra. It feeds on seeds, vegetable remains and small insects, and is strikingly homochromatic with the reddish or yellowish gray limonitic stones and boulders of its habitat characterized by a low and spiny Andean vegetation. Representative plants are Nassauvia axillaris, Adesmia subterrenea, Senecio, Larretia, Notothriche, Boopis, Astragalus, and Phacelia.

\section{DISCUSSION}

The recently discovered tropidurine lizards from Sierra de Famatina are a counterpart of the nearby related species Phymaturus palluma (Molina) and Liolaemus ruibali Donoso of the Andean Cordilleras. In correlation with the climatic effects of higher latitudes, these Andean species live at lower altitudes $(2800-3200 \mathrm{~m})$ in Uspallata and Calingasta highlands, western Argentine Mendoza and San Juan provinces. However the Famatina-mountains counterparts occur from 3600 to 4200 $\mathrm{m}$. Characteristic high-Andean spiny or cushion-like floral communities were observed from 3500 to $4500 \mathrm{~m}$ on the rocky slopes of the Sierra. Typical "Monte" formation, such as Creosote bush (Larrea nitida, L. divaricata) and Prosopis associations are reached there at about $2500 \mathrm{~m}$, being followed by a still poorly known transition zone $(2500-3500 \mathrm{~m})$ with predominant plants as Adesmia, Verbena, Neospartum, Mutisia, Astragalus, Senecio, Baccharis, Tagetes, Oenothera, Salvia, Calceolaria and Werneria. As pointed out in the remarks, Phymaturus mallimaccii is a less specialized saxicolous Phymaturus, living in broken conglomerates and ravines. Phymaturus palluma was reported as a characteristic inhabitant of crevices and geometrical fissures of basalts (Donoso, 1966; Cei and Castro, 1973). There it probably benefits of the quite uniform annual and monthly temperature of these rocks, according to their sun exposure and the depth of the crevices (Corte: pers. comm.). L. famatinae is a small dweller of the stony soil, hiding itself under the dense Poa and Festuca bunches, a very effective shelter also from the sudden low temperatures of montane environments. Thermal variations are very noticeable in this habitat. In summer months temperatures as low as $-14^{\circ} \mathrm{C}$ are very common at $7-8 \mathrm{AM}$, although in the same day $26^{\circ} \mathrm{C}$ in the shade and $43^{\circ} \mathrm{C}$ under the sun may be registered at noon or $2 \mathrm{PM}$.

The origin of endemic cold-adapted lizards from high Famatina mountains must be obviously related to selective factors through Pleistocene stages of glaciation. The snow line, localized at present at about $5500 \mathrm{~m}$, descended there to about $3000 \mathrm{~m}$, rising again during interglacials (Corte, 1976). Moreover at that time the vegetation line also descended below its present level, the approximate lower boundaries of high Andean floral associations lying at about 1200 meters. Altitudes below that level do not occur between the Famatina massif and Andean Cordilleras. Thus, during glacial stages, populations of former palluma-like and ruibali-like stocks could have been distributed from eastern Andean slopes to the uplifted Famatina mountains. With the rising snow line during dry interglacial stages some of them followed the retreat of cold Andean environments up to its present extreme altitudinal level, in the Cordilleran and Famatina mountains. Adaptive speciation may have been hastened during along interglacial under severe condition of topographic and genetic isolation.

The specific status both of Phymaturus palluma-P. mallimaccii and Liolaemus ruibali-L. famatinae can be supported by several significant morphological characters as well as by the different mobilities of serum protein fractions in parallel electrophoretic tests, shown in Fig. 5. Morphological relationships between $L$. ruibali and $L$. famatinae and $L$. ruibali and $L$. duellmani from Southern Mendoza Cordillera (Cei, 1978) indicate that these species constitute a montane Liolaemus species-group of weakly keeled, strongly autotomic forms, well differentiated by its heterogeneous lepidosis and color pattern. While several different Liolaemus species are present in 

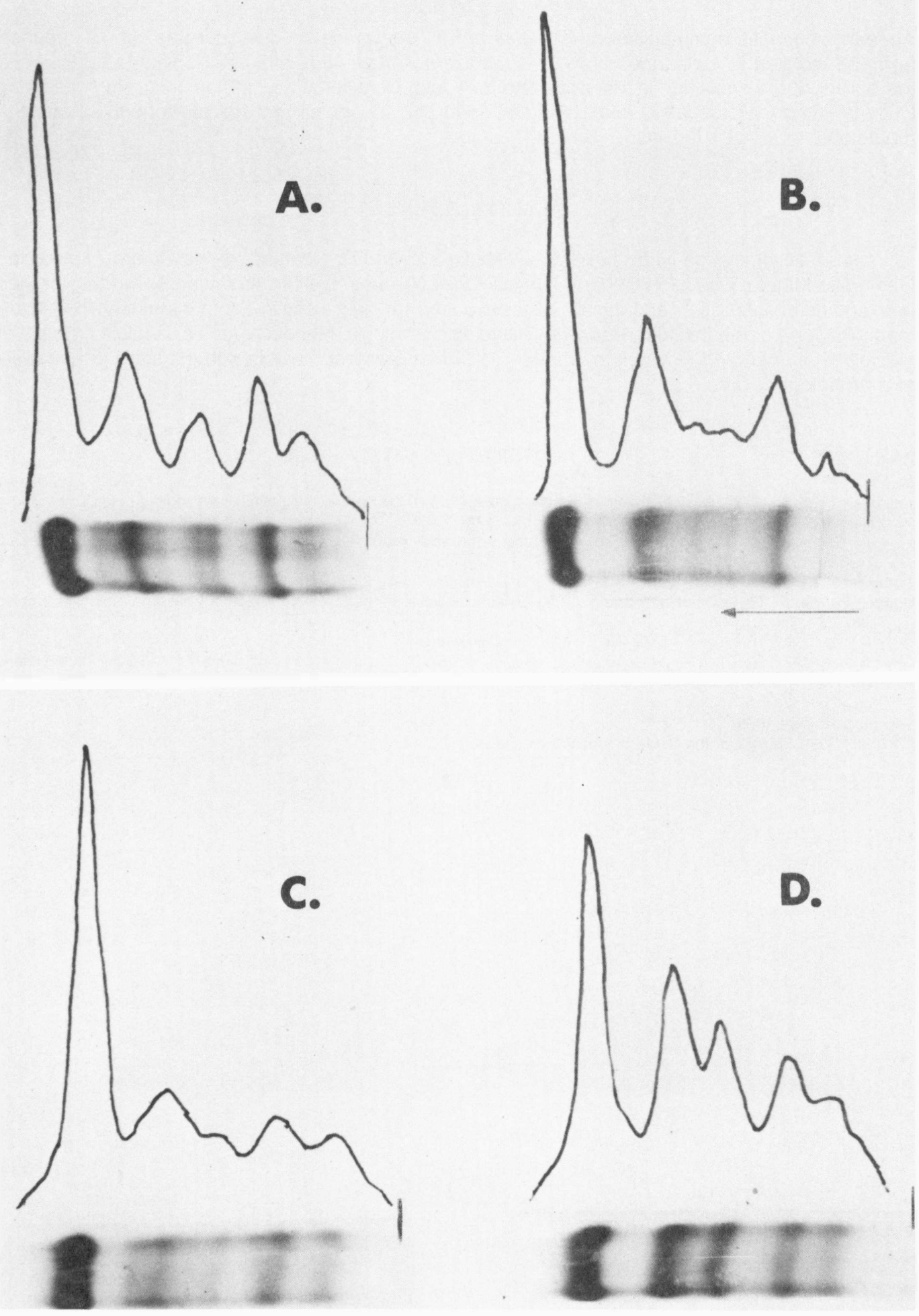

FIGURE 5. Electrophoretic serum protein patterns of iguanid lizards from Andean Cordillera and Sierra de Famatina mountains: A. Phymaturus palluma B. Phymaturus mallimaccii, C. Liolaemus ruibali, and D. Liolaemus famatinae. Different specific moving fractions are observed. 
Andean biocenotic communities of $L$. ruibali and $L$. duellmani, no other species can be reported from the isolated $L$. famatinae habitat. Also Liolaemus fitzgeraldi, a high-altitudinal lizard living on the border of the snow line in Mendoza and San Juan Cordilleras (Puente del Inca, Horcones, Las Cuevas, Cerro Mercedario, from 3000 to $3500 \mathrm{~m}$ ), is apparently absent from the Famatinä mountains.

\section{ACKNOWLEDGMENTS}

I wish acknowledge with thanks $H$. S. Mallimacci and R. Centeno, of the Centro Exploración Geolōgico-Minera, Dirección General Fabricaciones Militares, Ejercito Argentino, Mendoza, for their outstanding collaboration and logistic support during my field work in Famatina mountains. Also I thank A. Corte of the Instituto Argentino Glaciologia Nivologia, Mendoza, for his valuable criticism of glaciological data, and F. Videla of the IBA-UNC, Mendoza, for his help with the statistical analysis of morphological data.

\section{LITERATURE CITED}

Cei, J. M. 1978. A new species of Liolaemus (Sauria: Iguanidae) from the Andean mountains of the southern Mendoza volcanic region of Argentina. Occ. Papers Mus. Nat. Hist. Univ. Kansas 76:1-6.

and L. P. Castro. 1973. Taxonomic and serological researches on the Phymaturus patagonicus complex. J. Herpetol. 7:237-247.

Corte, A. E. 1976. Rock glaciers. Biuletyn Peryglacialny, Lodz 26:175-205

Donoso Barros, R. 1961. Three new lizards of the genus Liolaemus from the highest Andes of Chile and Argentina. Copeia 387-391.

1966. Reptiles de Chile. Univ. Chile, Santiago:458 pp.

Leanza, A. F. 1972. Geologia Regional Argentina. I Simposio Geologia Regional Argentina, Cordoba, 11-15 Sept. 1969:Sistema del Famatina, by E. De Alba. Edit. Acad. Nac. Ciencias, Cordoba: 143-184.

Accepted 19 Sept 1979

Copyright 1980 Society for the Study of Amphibians and Reptiles 